\title{
Academic performance of students in other university courses after dropping out of pharmacy school
}

\author{
Ayodapo O Jegede (iD, Hezekiah A Adebiyi, Wilson O Erhun (iD \\ Department of Clinical Pharmacy and Pharmacy Administration, Faculty of Pharmacy, Obafemi Awolowo University, Nigeria
}

\author{
Keywords \\ Academic \\ Performance \\ College Achievement \\ Pharmacy \\ Students \\ Drop Out \\ Nigeria \\ Correspondence \\ Ayodapo O Jegede \\ Department of Clinical Pharmacy \\ and Pharmacy Administration \\ Faculty of Pharmacy \\ Obafemi Awolowo University \\ Ile-Ife \\ Osun-State \\ Nigeria \\ dapojegede@oauife.edu.ng
}

\begin{abstract}
Background: Students drop out of pharmacy school for reasons that are not fully explored and are then enrolled in other courses. The college achievement of these students in their new courses will be relevant to curriculum review. Aim: To determine the reasons for students' drop out from pharmacy school and evaluate the academic competence of such students in their new undergraduate courses. Method: This was a cross-sectional study comprising 49 students who dropped out of the Faculty of Pharmacy, Obafemi Awolowo University. The study used descriptive and inferential statistics to explore perceived reasons for pharmacy students' drop out and their performance in new courses. Result: The results showed that the major reasons for students' drop out were excessive workload (Weighted Average [WA]=4.43/5.0), poor time management ( $W A=4.16 / 5.0)$ and inadequate learning facilities ( $W A=4.04 / 5.0)$. The students performed relatively better in their new courses. Conclusion: The study identified the reasons for pharmacy students' drop out as excessive workload, poor time management among others. Pharmacy student who dropped out performed better academically in other university courses.
\end{abstract}

\section{Introduction}

The reasons why students drop out from university has been investigated by a number of researchers (Mannan, 2007; Kirmani \& Siddiquah, 2008; Pariat, Rynjah, \& Kharjana, 2014). Undergraduates' drop out has been frequently defined in terms of 'non-retention', 'failing to progress', 'non-continuation' and 'non-completion' (Department for Children, Education, Lifelong Learning and Skill, 2009). Withdrawn undergraduates are frequently depicted as having a specific character profile or as lacking important attributes essential to college achievement (Rumberger \& Lim, 2008). Such generalisations are strengthened by talk of student withdrawal that labels individuals as failures for not having completed their university programmes of study (Ott, 1988). University withdrawal occurs among even the high-flyer students, so the phenomenon is not merely a matter of the withdrawal of academic misfits (Johnson \& Buck, 1995).
Undergraduate withdrawal is the consequence either of an institutional decision or a personal decision therefore a distinction must be made between these two groups. The institutional decision is usually based upon academic competency of the student, although misconduct such as plagiarism and cheating make some withdrawals necessary (Mokula \& Lovemore, 2014). Kleijn, Vander and Topman (1994) defined academic competency as the proficiency of students with respect to the content taught during courses over the past academic year and their ability to comprehend the course material. Good academic competence is an indicator that the student is able to manage and cope with the amount of study material for examinations and/or tests, and also provides an indication of whether the curriculum is interesting enough for students to enjoy their classes (Gettinger \& Seibert, 2002). Students with better academic competence would probably have better academic performance and are less likely to be withdrawn (Sujit, 2006). 
According to Pinto et al. (2001), one of the causes of a decline in academic performance is financial stress. This was corroborated by Mehta et al. (2011) who suggested that in addition to financial stress, time management skills also play a significant role in determining whether a student will complete an academic programme or not. Planning in advance, prioritising of work, test preparation, and following schedules are some of activities performed by undergraduates that require good time management skills (Talib \& Sansgiry, 2012). Powell (2004) established that good academic performance may be achieved with balanced time management and study techniques.

It is the interaction between an individual and an institution that could affect academic stress resulting in students' academic performance and psychological state, and forming the basis for institutional and personal withdrawal decisions (Oduwaiye et al., 2017). Greenberg and Valletutti (1980), stated that a good psychological balance and an efficient coping mechanism is needed to deal with academic stress. Coping techniques such as proper utilisation of time, involvement in leisure related activities, optimistic appraisal, and support from friends and family often relieve stress in students (Blake \& Vandiver, 1988).

An individual's self-esteem is another factor that affects college achievement as stated by Wills (1991). Studies conducted by Dennis, Phinney and Chuateco (2005) and Nicpon et al. (2006) reported that students who are socially inactive tend to be more isolated, attain poor grades and are more at risk of withdrawing from college. A decline in the academic performance and adjustment is seen among students who are lonely and socially inactive in college thus making them unable to utilise the social resources available on campus.

The annual American Association of Colleges of Pharmacy (AACP) institutional research data-gathering and analysis system designed to gather information pertaining to United States (US) pharmacy colleges and schools reveals an increase in attrition rate from $10.3 \%$ (2014 class) to $12.6 \%$ (2019 class) (AACP, 2014; AACP, 2019). The attrition rate studied includes academic dismissals, student withdrawals, and delayed graduation. In a similar study conducted in the United Kingdom, attrition rates in pharmacy for students who completed their studies in 2004 indicates that attrition had risen to $13.9 \%$ following a progressive increase from 1996 (9\%) and reaching a peak in the 1997 cohort (19\%) before falling in 1998 (11.1\%) and rising again (Hassell et al., 2007). In developing countries, an increasing drop out rate is also a frequent theme (Graeff-Martins et al., 2006). Moeketsi and Maile (2008) highlighted the drop out rate as reported by the
Department of Education in 2005 to be as high as $80 \%$ in some institutions in South Africa. In Nigeria, the academic curriculum for the training of pharmacists was previously geared towards producing 'drug experts' (Hassali, 2011; Abdulkarem, 2014). The Pharmacists Council of Nigeria organised a pharmacy curriculum conference in 2001, where the curriculum was reviewed in line with the changing roles of the pharmacist (Erhun \& Rahman, 1989; Akubue \& Adenika, 2009). Clinical pharmacy was incorporated for better patient/drug management and this also increased the total credit hours in the undergraduate pharmacy curriculum. (Ikhile \& Chijioke-Nwauche, 2016; Fakeye, Adisa \& Erhun, 2017).

In Nigerian universities, the entry requirements for the Bachelor of Pharmacy (B.Pharm.) five-year degree programme includes University Tertiary Matriculation Examination (conducted by Joint Admission and Matriculation Board) where candidates applying into the first year of the programme are required to have credit passes in five subjects including English, Mathematics, Physics, Chemistry, and Biology in the Senior Secondary School Certificate Examination or its equivalent, that qualifies them for a further examination conducted by the various universities. Another mode of entry into pharmacy school is the direct entry (DE). DE admission is to second year (200 level) of the pharmacy programme and it is offered to those who obtain sufficient points in Physics, Chemistry, and Biology at GCE ' $A$ ' level or its equivalent or through other mode of entry such as intra- and interuniversity transfer.

At the Obafemi Awolowo University, Nigeria, the number of required courses taken in the various years are 10 (Part II), 13 (Part III) and 12 (Part IV). A candidate who fails in not more than three of the required courses in Parts II to IV may be allowed to resit the examination in those papers once only provided his overall average is not less than $50 \%$. Otherwise, the candidate shall be required to repeat the year. A candidate who fails in not more than two of the 12 courses in Part V (final year) may be allowed to resit the examination in two papers once only provided his overall average is not less than $50 \%$.

The conditions for repeating a year in Parts II to IV are:

a. A candidate who fails in a referred subject or course shall be required to repeat the year as no further reference shall be allowed;

b. A candidate who fails in more than the allowable number of subjects or courses and whose overall average is not less than $40 \%$ may be allowed to repeat the year; otherwise he shall be required to withdraw from the Faculty. 
A candidate who fails in either the Part II, III or IV examinations at the second attempt shall be required to withdraw from the Faculty. These are the students classified as drop outs in this study. Their non-completion of the pharmacy programme is as a result of poor academic performance. Such students subsequently transferred to other courses in the same university or to other institutions.

The study was undertaken to determine the reasons for students' drop out from pharmacy school as well as evaluate the academic performance of such students in their new undergraduate courses. This is needed to enable programme administrators to draw meaningful and adequate inferences about the conditions that contributed to the students' withdrawal from pharmacy school. This will be an important input in curriculum development as well as college administration to design and implement policies that will improve learning outcomes and hopefully reduce rate of dropout. Parents/sponsors would also better appreciate the factors that affected the performance of their wards/sponsored students.

Student failure has a cost component because failure creates additional education cost and the cost of failure is predominantly borne by the student, directly through university fees and indirectly through the opportunity cost of his or her time (Dobson \& Sharma, 1999). For students repeating a year, they tend to bear the burden of the private cost for the particular year again and this may cause financial strain and the incurring of debt for students who come from low socioeconomic background. Identifying the reasons for academic failure in pharmacy will avoid unnecessary additional expenses borne by parents, guardians, sponsors and/or students.

\section{Methods}

\section{Study site}

The study was conducted at Obafemi Awolowo University (OAU), lle-Ife, Nigeria during the 2018/2019 academic session. The Faculty of Pharmacy at the Obafemi Awolowo University is the premier faculty of pharmacy in Nigeria (Obafemi Awolowo University, 2019). It was established in 1962.

\section{Study design and ethical approval}

The study was a cross-sectional survey of students who dropped out (49) at different levels from the Faculty of Pharmacy, OAU over the last five academic sessions
(2013/2014 to $2017 / 2018)$ using a self-administered pre-tested structured questionnaires. The entry year and enrolment figure for each academic session included in the study are as follows: $2013 / 2014=125 ; 2014 / 2015=125$; 2015/2016=142; 2016/2017=123; and 2017/2018=127.

Ethical approval for the study was obtained from the Institute of Public Health, OAU (\#IPHOAU/12/1410). Consent was obtained from respondents before they were administered the questionnaire.

\section{Study population and sampling method}

The population and contacts, when available, of the students withdrawn from the Faculty within the period of 2013/2014 and 2017/2018 academic sessions was obtained from General Office of the Faculty. Based on a preliminary examination, a purposive sample size was determined using Taro Yamane method (1967) and the sample was selected using stratified random sampling method. The total population of students withdrawn within the period of study was 60; this was used to calculate the sample size of the study. A sample size was needed to assure the reliability of the study. Forty-nine out of the total of 60 students withdrawn from the Faculty during this period consented and participated in the study. No student had been withdrawn from the Faculty in the final year (500 level) in the period under study. Therefore, the data employed in this study was obtained directly from students withdrawn from 2nd year (200 level) to 4th year (400 level). First year were not included because they are not considered to be students in the Faculty of Pharmacy until their 2nd year (professional year).

\section{Inclusion and exclusion criteria}

Only pharmacy students withdrawn in the last five academic sessions, and who consented to participate in the study were enrolled. Also, only participants who had enrolled in new programmes were included in this study.

\section{Research instruments and data collection procedure}

This study used a pre-tested online self-administered questionnaire in English. The questionnaire was developed by adapting the questionnaire used in previous studies (Rushforth, 2007; Hannah et al., 2017). The questionnaire was designed to evaluate students' perception of their withdrawal from pharmacy school, and assess the students' academic fulfilment in their new programmes. The internal consistency of the questionnaire was assessed using the SPSS v.20 software (IBM Corp, 2011). It was 
estimated by the coefficient alpha index with reference to the Cronbach's alpha value. The Cronbach's coefficient alpha values for scales measuring causes of withdrawal (0.8) indicates acceptable reliability (Sieber, 1980). To establish content and face validity, the questionnaire was reviewed by an expert researcher from the Faculty of Pharmacy. All corrections were effected in the final version of the questionnaire.

The questionnaire was divided into five sections: Section I included questions on demographic data; Sections II, III and IV included questions that provided the perception of the respondents on the possible causes of their drop out (withdrawal) from pharmacy school. Here, the participants voluntarily responded to each question on a 5-point Likert scale where 1=Strongly Agree (SA), 2=Agree (A), 3=Neutral $(N)$, 4=Disagree (D), 5=Strongly Disagree (SD) was utilised. Section $\mathrm{V}$ included questions that highlighted the level of academic satisfaction of these students in their new department(s).

Mostly, the authors met with the withdrawn students and a rapport was established to obtain their consent and prepare the ground for data collection. Occasionally a friend or close associate to the respondents (identified by classmates) were recruited to facilitate willingness to participate in the study. Alternatively, for the students who could not be reached in person, the weblink of the questionnaire was distributed to them via the WhatsApp app. The questionnaire informed the participants of the purpose of the study, the assurance of anonymity and the importance of their participation in the study.

\section{Data analysis and statistics}

Coding and re-coding of data from respondents were done and subsequently analysed for descriptive and inferential statistics with the aid of the SPSS v.20 (IBM Corp, 2011). Descriptive statistics such as frequencies, percentages and mean were used to categorise the variables while inferential statistics such as $t$-test was used to explore the relationship between the Grade Index (GI) and Grade Point Average (GPA) and correlations to determine the relationship between the variables which are likely to cause withdrawal from pharmacy school and those which are likely to have an impact on the students' performance in their new programmes $(p<0.05)$.

\section{Results}

\section{Demographic characteristics}

The response rate for the instrument was $100 \%$. Table I shows the demographics of participants. There were more males (65\%) than females (35\%) and most of the respondents were aged between 23-25 (67.3\%). Most of the respondents were withdrawn at 200 level (46.9\%) and the least from 400 level (14.2\%). A higher percentage of the respondents had interest in studying pharmacy (75.5\%) and chose pharmacy as first choice during admission (83.7\%).

Table I: Participants' Demographics ( $n=49)$

\begin{tabular}{lcc}
\hline Variables & Frequency & (\%) \\
\hline Gender & 17 & 34.7 \\
Female & 32 & 65.3 \\
Male & & \\
\hline Age & 0 & 0 \\
$17-19$ & 4 & 8.2 \\
$20-22$ & 33 & 67.3 \\
$23-25$ & 12 & 24.5 \\
$26 \&$ Above & 23 & \\
\hline Level at the time of withdrawal & 46.9 \\
200 & 19 & 38.8 \\
300 & 7 & 14.2 \\
400 & & \\
\hline Session at the time of withdrawal & 10 & 20.4 \\
$2013 / 2014$ & 9 & 18.4 \\
$2014 / 2015$ & 17 & 34.7 \\
$2015 / 2016$ & 12 & 24.5 \\
$2016 / 2017$ & 1 & 2.0 \\
$2017 / 2018$ & 37 & 75.5 \\
\hline Were you always interested in studying pharmacy? & & \\
No & 12 & 24.5 \\
Yes & 31 & 83.7 \\
\hline Was pharmacy your first choice of course during admission? & \\
No & 8 & \\
Yes & & \\
\hline & & \\
\hline
\end{tabular}

Table II: New faculties of study of the respondents

\begin{tabular}{lcc}
\hline New Faculty & Frequency & (\%) \\
\hline Agriculture & 14 & 28.6 \\
Sciences & 12 & 24.5 \\
Social sciences & 16 & 32.7 \\
Education & 2 & 4.08 \\
Technology & 2 & 4.08 \\
Pharmacy (another school) & 2 & 4.08 \\
Health sciences & 1 & 2.04 \\
\hline
\end{tabular}

Table II shows the new faculties the withdrawn students transferred to and revealed that most respondents transferred to the Faculty of Social Sciences (32.7\%), followed by those who transferred to the Faculty of 
Agriculture (28.6\%). Two students transferred to Faculty of Health Sciences and one transferred to the Faculty of Pharmacy at another university.

\section{Perception of students regarding the likely causes of their withdrawal from pharmacy school}

Table III(a) presents a summary of the various causes of withdrawal under a broad distinction of either being institutional/academic-related or personal-related. Institutional/academic-related causes being 'excessive workload' (67.3\%), 'negligence of academic work' (47.0\%), 'poor comprehension of academic work' (59.2\%), 'inadequate learning facilities' $(55.1 \%)$, and personalrelated causes being 'family and financial stress' (71.4\%), 'poor time management' (83.7\%), 'engagement in extracurricular activities' (71.4\%), 'lack of interaction with other colleagues' (59.2\%). Table III(b) shows the perception of the students about these likely causes of their withdrawal from pharmacy school and the weighted average (WA) response. Most of the respondents agreed that excessive workload (WA=4.43), poor time management (WA=4.16), inadequate learning facilities ( $W A=4.04)$, engagement in extracurricular activities (WA=3.88), financial stress (WA=3.74), family stress $(W A=3.53)$ and poor comprehension of courses taught (WA=3.51) were responsible for their failures. It also showed that they were indifferent about negligence of academic work $(W A=3.14)$ and lack of interaction with colleagues (WA=2.83) being strong influences in their withdrawal. The items were further correlated with the use of Spearman Rho computations to show if any relation existed between the items. The results showed that negligence of academic work strongly correlated with poor time management $(p=0.000)$ and weakly with poor comprehension of academic work $(p=0.015)$ and engagement in extracurricular activities $(p=0.014)$. Also, there was a strong relationship between family stress and poor time management $(p=0.004)$ and a weak relationship between family stress and inadequate learning facilities $(p=0.024)$. Engagement in extracurricular activities strongly correlated with excessive workload $(p=0.004)$, financial stress $(p=0.009)$, inadequate learning facilities $(p=0.001)$ and poor comprehension of academic work $(p=0.008)$, while correlating weakly with poor time management $(p=0.015)$. A relationship existed between excessive workload and inadequate learning facilities $(p=0.014)$ and poor comprehension of academic work $(p=0.010)$. Inadequate learning facilities correlated strongly with poor time management $(p=0.003)$ but weakly with poor comprehension of academic work $(p=0.031)$. Finally, poor comprehension of academic work had a strong relationship with poor time management skill $(p=0.003)$.

Table III(a): Causes of withdrawal from pharmacy school ( $n=49$ )

\begin{tabular}{lcc}
\hline Student Category/Response & Frequency & $\begin{array}{c}\text { \% of } \\
\text { Sample }\end{array}$ \\
\hline Institutional/academic-related causes & 29 & 59.2 \\
Poor comprehension of course content & 33 & 67.3 \\
Excessive workload & 27 & 55.1 \\
Inadequate learning facilities & 23 & 47.0 \\
Negligence of academic work & 35 & 71.4 \\
\hline Personal-related causes & 35 & 71.4 \\
Family stress & 41 & 83.7 \\
Financial stress & 35 & 71.4 \\
Poor time management skill & 29 & 59.2 \\
Engagement in extracurricular activities & & \\
Lack of interaction with colleagues & &
\end{tabular}

Table III(b): Perception of students about the likely causes of their withdrawal from pharmacy school

\begin{tabular}{|c|c|c|c|c|c|c|}
\hline Variables & $\begin{array}{c}\text { SD } \\
f(\%)\end{array}$ & $\begin{array}{c}D \\
f(\%)\end{array}$ & $\begin{array}{c}N \\
f(\%)\end{array}$ & $\begin{array}{c}A \\
f(\%)\end{array}$ & $\begin{array}{c}\text { SA } \\
f(\%)\end{array}$ & WA \\
\hline Academic incompetence (Poor comprehension of course content) & $5(10.2)$ & $11(22.4)$ & $4(8.2)$ & $12(24.5)$ & $17(34.7)$ & 3.51 \\
\hline Family stress & $1(2.0)$ & $10(20.4)$ & $3(6.1)$ & $16(32.7)$ & 19 (38.8) & 3.53 \\
\hline Engagement in extracurricular activities & $2(4.1)$ & $7(14.3)$ & $5(10.2)$ & $16(32.7)$ & 19 (38.8) & 3.88 \\
\hline Excessive workload & $0(0.0)$ & $3(6.1)$ & $3(6.1)$ & $13(26.5)$ & $30(61.2)$ & 4.43 \\
\hline Inadequate learning facilities & $1(2.0)$ & $7(14.3)$ & $4(8.2)$ & $14(28.3)$ & $23(46.9)$ & 4.04 \\
\hline Negligence of academic work & $6(12.2)$ & $16(32.7)$ & $4(8.2)$ & $11(22.4)$ & $12(24.5)$ & 3.14 \\
\hline Poor time management skill & $2(4.1)$ & $3(6.1)$ & $3(6.1)$ & $18(36.1)$ & $23(46.9)$ & 4.16 \\
\hline Financial stress & $0(0.0)$ & $10(20.4)$ & $4(8.2)$ & $24(49.0)$ & $11(22.4)$ & 3.74 \\
\hline Lack of interaction with colleagues & $10(20.4)$ & 15 (30.6) & $5(10.2)$ & $11(22.4)$ & $8(16.3)$ & 2.83 \\
\hline
\end{tabular}

Causes of Withdrawal $=2.20(0.968 ;$ Cronbach alpha $=0.8)$ 
Table IV: Correlation analysis of the causes of withdrawal

\begin{tabular}{|c|c|c|c|c|c|c|c|c|c|}
\hline & & (a) & (b) & (c) & (d) & (e) & (f) & (g) & (h) \\
\hline \multirow[t]{2}{*}{ Negligence of Academic work (a) } & SR & 1.000 & 0.257 & $0.366^{*}$ & 0.201 & 0.088 & 0.208 & $0.359^{*}$ & $0.515^{* *}$ \\
\hline & $S(2-t)$ & & 0.088 & 0.014 & 0.192 & 0.565 & 0.176 & 0.015 & 0.000 \\
\hline \multirow[t]{2}{*}{ Family stress (b) } & SR & 0.257 & 1.000 & 0.121 & 0.246 & 0.109 & $0.340^{*}$ & 0.216 & $0.423^{* *}$ \\
\hline & $S(2-t)$ & 0.088 & & 0.434 & 0.107 & 0.474 & 0.024 & 0.154 & 0.004 \\
\hline \multirow[t]{2}{*}{ Engagement in extracurricular activities (c) } & SR & $0.366^{*}$ & 0.121 & 1.000 & $0.429^{* *}$ & $0.386^{* *}$ & $0.497^{* *}$ & $0.395^{* *}$ & $0.365^{*}$ \\
\hline & $S(2-t)$ & 0.014 & 0.434 & & 0.004 & 0.009 & 0.001 & 0.008 & 0.015 \\
\hline \multirow[t]{2}{*}{ Excessive workload (d) } & SR & 0.201 & 0.246 & $0.429^{* *}$ & 1.000 & 0.284 & $0.368^{*}$ & $0.379^{*}$ & 0.241 \\
\hline & $S(2-t)$ & 0.192 & 0.107 & 0.004 & & 0.062 & 0.014 & 0.010 & 0.111 \\
\hline \multirow[t]{2}{*}{ Financial stress (e) } & SR & 0.088 & 0.109 & $0.386^{* *}$ & 0.284 & 1.000 & 0.279 & 0.268 & 0.178 \\
\hline & $S(2-t)$ & 0.565 & 0.474 & 0.009 & 0.062 & & 0.067 & 0.075 & 0.241 \\
\hline \multirow[t]{2}{*}{ Inadequate learning facilities (f) } & SR & 0.208 & $0.340^{*}$ & $0.497^{* *}$ & $0.368^{*}$ & 0.279 & 1.000 & $0.327^{*}$ & $0.430^{* *}$ \\
\hline & $S(2-t)$ & 0.176 & 0.024 & 0.001 & 0.014 & 0.067 & & 0.031 & 0.003 \\
\hline \multirow[t]{2}{*}{ Poor comprehension of academic work (g) } & SR & $0.359^{*}$ & 0.216 & $0.395^{* *}$ & $0.379^{*}$ & 0.268 & $0.327^{*}$ & 1.000 & $0.440^{* *}$ \\
\hline & $S(2-t)$ & 0.015 & 0.154 & 0.008 & 0.010 & 0.075 & 0.031 & & 0.003 \\
\hline \multirow[t]{2}{*}{ Poor time management skill (h) } & SR & $0.515^{* *}$ & $0.423^{* *}$ & $0.365^{*}$ & 0.241 & 0.178 & $0.430^{* *}$ & $0.440^{* *}$ & 1.000 \\
\hline & $S(2-t)$ & 0.000 & 0.004 & 0.015 & 0.111 & 0.241 & 0.003 & 0.003 & \\
\hline
\end{tabular}

When asked about the effects of class size on their performance, the respondents indicated that there was insufficient laboratory apparatus for students (WA=4.06), stiff competition (WA=3.76) and congested lecture theatres $(W A=3.67)$ because of the large class sizes. However, the respondents disagreed to part adviser to student ratio being affected by class size (WA=2.29).

\section{The level of academic fulfilment of withdrawn pharmacy students in their new courses of study}

Figure $A$ shows a graph of the grade point index of respondents when in pharmacy school and it shows the highest number fell between 2.5-3.5 (83.0\%), none got higher than 3.5. Figure $A$ also shows the GPA of the respondents in their new programmes and reveals the higher proportion fell between 2.5-3.5 (48.9\%) and a few had higher than 3.5 scores (12.8\%). Across the departments there was an improvement in the GPA of respondents. The $t$-test analysis result shows however, that there was no statistical difference in the $\mathrm{Gl}$ in pharmacy and GPA in the new programme $(p=0.341)$.

Table $\mathrm{V}$ shows the level of academic competence of withdrawn pharmacy students in their new courses. The respondents strongly agreed to having a good understanding of the course content in their courses (WA=4.59). They all disagreed to their engagement in other activities affecting their academic performance negatively (WA=2.12).

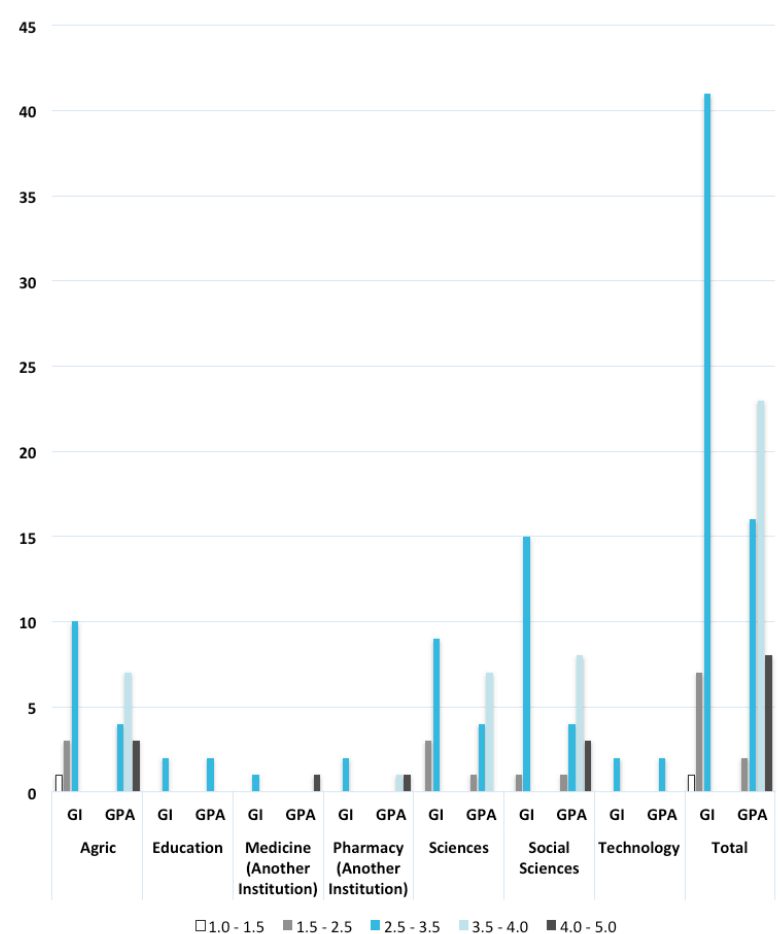

Figure A: Cumulative Grade Index in pharmacy versus Grade Point Average of respondents in their new programmes

Table VI shows the correlation analysis of the factors affecting the academic performance of the withdrawn 
students in their new courses. Good comprehension of course content had a strong relationship with being able to easily manage course workload $(p=0.000)$ and interest in the programme $(p=0.006)$. It also correlated with the cumulative GPA $(p=0.024)$. Being interested in the programme had a relationship with being able to easily manage course load ( $p=0.002)$, positive effect of engaging in other activities $(p=0.046)$ and engaging in other activities having a negative impact on performance $(p=0.014)$. The positive effect of engaging in other activities had a relationship with being able to combine study and leisure time $(p=0.000)$ and engaging in other activities having a negative impact on performance $(p=0.000)$.

Table V: Level of academic competence of withdrawn pharmacy students in their new programmes of study

\begin{tabular}{|c|c|c|c|c|c|c|}
\hline Variables & $\begin{array}{l}\text { SD } \\
f(\%)\end{array}$ & $\begin{array}{c}D \\
f(\%)\end{array}$ & $\begin{array}{c}N \\
f(\%)\end{array}$ & $\begin{array}{c}A \\
f(\%)\end{array}$ & $\begin{array}{c}\text { SA } \\
f(\%)\end{array}$ & WA \\
\hline $\begin{array}{l}\text { Good comprehension of } \\
\text { course content (a) }\end{array}$ & $\begin{array}{c}0 \\
(0)\end{array}$ & $\begin{array}{c}1 \\
(2.0)\end{array}$ & $\begin{array}{c}1 \\
(2.0)\end{array}$ & $\begin{array}{c}15 \\
(30.6)\end{array}$ & $\begin{array}{c}32 \\
(65.3)\end{array}$ & 4.59 \\
\hline $\begin{array}{l}\text { Easily manage the course } \\
\text { load (b) }\end{array}$ & $\begin{array}{c}0 \\
(0)\end{array}$ & $\begin{array}{c}2 \\
(4.1)\end{array}$ & $\begin{array}{c}1 \\
(2.0)\end{array}$ & $\begin{array}{c}18 \\
(36.7)\end{array}$ & $\begin{array}{c}28 \\
(57.1)\end{array}$ & 4.47 \\
\hline $\begin{array}{l}\text { Easily manage the study } \\
\text { materials (c) }\end{array}$ & $\begin{array}{c}1 \\
(2.0)\end{array}$ & $\begin{array}{c}4 \\
(8.2)\end{array}$ & $\begin{array}{c}2 \\
(4.1)\end{array}$ & $\begin{array}{c}20 \\
(40.8)\end{array}$ & $\begin{array}{c}22 \\
(44.9)\end{array}$ & 4.18 \\
\hline Interest (d) & $\begin{array}{c}1 \\
(2.0)\end{array}$ & $\begin{array}{c}11 \\
(22.4)\end{array}$ & $\begin{array}{c}3 \\
(6.1)\end{array}$ & $\begin{array}{c}14 \\
(28.6)\end{array}$ & $\begin{array}{c}20 \\
(40.8)\end{array}$ & 3.83 \\
\hline $\begin{array}{l}\text { Easy to combine study and } \\
\text { leisure time (e) }\end{array}$ & $\begin{array}{c}0 \\
(0)\end{array}$ & $\begin{array}{c}5 \\
(10.2)\end{array}$ & $\begin{array}{c}2 \\
(4.1)\end{array}$ & $\begin{array}{c}18 \\
(36.7)\end{array}$ & $\begin{array}{c}24 \\
(49.0)\end{array}$ & 4.24 \\
\hline $\begin{array}{l}\text { Engaging in other activities } \\
\text { have positive impact (f) }\end{array}$ & $\begin{array}{l}0 \\
0\end{array}$ & $\begin{array}{c}3 \\
(6.1)\end{array}$ & $\begin{array}{c}1 \\
(2.0)\end{array}$ & $\begin{array}{c}19 \\
(38.8)\end{array}$ & $\begin{array}{c}26 \\
(53.1)\end{array}$ & 4.39 \\
\hline $\begin{array}{l}\text { Engaging in other activities } \\
\text { have negative impact (g) }\end{array}$ & $\begin{array}{c}16 \\
(32.7)\end{array}$ & $\begin{array}{c}23 \\
(46.9)\end{array}$ & $\begin{array}{c}2 \\
(4.1)\end{array}$ & $\begin{array}{c}4 \\
(8.2)\end{array}$ & $\begin{array}{c}4 \\
(8.2)\end{array}$ & 2.12 \\
\hline
\end{tabular}

SD - Strongly Disagree; D - Disagree; N - Neutral; A - Agree; SA - Strongly Agree
Undergraduate withdrawals are usually institutionally driven and are rarely a personal decision, and most of the withdrawals from pharmacy schools are predicated on the academic performance of the students (Johnson \& Buck, 1995). The results showed more males than females were withdrawn from pharmacy school within the study period similar to the findings of Cameron et al. (2010) but contradicts the position of Blaney and Mulkeen (2008) that female undergraduates were more likely to be withdrawn. None of the respondents were within the age range of 17 to 19 years. Yorke and Longden, (2008) revealed that older undergraduates have different problems in comparison to undergraduates who had quite recently left secondary level education. They were more prone to drop out for social reasons, external to the college condition, for example, family and budgetary commitments as observed by Gavin (2012).

The majority of the respondents were withdrawn in 200 level which agrees with the study of Ortiz-Lozano et al. (2018) who found that students are prone to drop out at the lower levels in the university. One can argue that this might be due to the naivety which comes along with being exposed to a new environment. They are fresh out of secondary school and might not be mentally equipped to meet the arduous demands of the university system but as they progressed in the programme the rate of withdrawal decreased (Dyson \& Renk, 2006). The study established also that the respondents' withdrawal was not premised on their initial interest in studying pharmacy as most of them indicated interest in studying pharmacy and chose pharmacy as first choice during admission. This is not in agreement with the works of Grayson and

Table VI: Correlation analysis of the factors affecting the academic performance of the withdrawn students in their new departments

\begin{tabular}{|c|c|c|c|c|c|c|c|c|c|}
\hline & & (a) & (b) & (c) & (d) & (e) & (f) & (g) & (h) \\
\hline \multirow[t]{2}{*}{ Good comprehension of course content (a) } & SR & 1.000 & $0.724^{* *}$ & -0.089 & $0.398^{* *}$ & -0.097 & -0.076 & 0.025 & $0.330^{*}$ \\
\hline & $S(2-t)$ & & 0.000 & 0.551 & 0.006 & 0.516 & 0.609 & 0.867 & 0.024 \\
\hline \multirow[t]{2}{*}{ Easily manage the course load (b) } & SR & $0.724^{* *}$ & 1.000 & 0.055 & $0.440^{* *}$ & 0.038 & -0.073 & -0.012 & -0.015 \\
\hline & $S(2-t)$ & 0.000 & & 0.713 & 0.002 & 0.800 & 0.623 & 0.935 & 0.921 \\
\hline \multirow[t]{2}{*}{ Easily manage the study material (c) } & SR & -0.089 & 0.055 & 1.000 & 0.047 & 0.158 & 0.256 & 0.240 & 0.061 \\
\hline & $S(2-t)$ & 0.551 & 0.713 & & 0.758 & 0.295 & 0.082 & 0.109 & 0.685 \\
\hline \multirow[t]{2}{*}{ Interest (d) } & SR & $0.398^{* *}$ & $0.440^{* *}$ & 0.047 & 1.000 & 0.261 & $0.295^{*}$ & $0.364^{*}$ & 0.023 \\
\hline & $S(2-t)$ & 0.006 & 0.002 & 0.758 & & 0.083 & 0.046 & 0.014 & 0.880 \\
\hline \multirow[t]{2}{*}{ Easy to combine study and leisure time (e) } & SR & -0.097 & 0.038 & 0.158 & 0.261 & 1.000 & $0.604^{* *}$ & 0.256 & 0.051 \\
\hline & $S(2-t)$ & 0.516 & 0.800 & 0.295 & 0.083 & & 0.000 & 0.083 & 0.735 \\
\hline \multirow{2}{*}{$\begin{array}{l}\text { Engaging in other activities have positive } \\
\text { impact (f) }\end{array}$} & SR & -0.076 & -0.073 & 0.256 & $0.295^{*}$ & $0.604^{* *}$ & 1.000 & $0.607^{* *}$ & 0.074 \\
\hline & $S(2-t)$ & 0.609 & 0.623 & 0.082 & 0.046 & 0.000 & & 0.000 & 0.621 \\
\hline \multirow{2}{*}{$\begin{array}{l}\text { Engaging in other activities have negative } \\
\text { impact }(\mathrm{g})\end{array}$} & SR & 0.025 & -0.012 & 0.240 & $0.364^{*}$ & 0.256 & $0.607^{* *}$ & 1.000 & 0.070 \\
\hline & $S(2-t)$ & 0.867 & 0.935 & 0.109 & 0.014 & 0.083 & 0.000 & & 0.645 \\
\hline \multirow[t]{2}{*}{ Cumulative GPA (h) } & SR & $0.330^{*}$ & -0.015 & 0.061 & 0.023 & 0.051 & 0.074 & 0.070 & 1.000 \\
\hline & $S(2-t)$ & 0.024 & 0.921 & 0.685 & 0.880 & 0.735 & 0.621 & 0.645 & \\
\hline
\end{tabular}


Grayson (2003) and Fisher and Engemann (2009) who asserted that higher withdrawal occurred with students who were not interested in their courses of study and were a poor 'fit'. The study considered a five-year period which would have made it possible for some students withdrawn from pharmacy school to have finished their new programmes as observed from the results.

To facilitate data reporting, the responses were initially summarised and categorised into institutional/academicrelated or personal-related causes of drop-out. This synopsis allowed the participants the choice of selecting either or both of the causes. Research has shown that academic performance of undergraduates is affected by numerous factors which can be internal or external as posited by Hansen (2000). When reviewing the factors responsible for respondents' being withdrawn from school, there was a combination of both factors in this study. The internal factors included excess workload, inadequate learning facilities and poor comprehension of courses taught (Okogbaa et al., 2020). The external factors included, poor time management, engagement in extracurricular activities, financial stress and family stress. Ali et al. (2009) and Akomolafe and Adesua (2016) found that academic performance has a direct relationship with learning facilities which tallies with the results of this study. Respondents who agreed that negligence of academic work was responsible for their failure also indicated, poor time management (Schere et al., 2017), poor comprehension of academic work and engagement in extracurricular activities as corroborated by Buckley and Lee (2018) who found that students who participated in extracurricular activities complained about negligence of academic work. Students who manage their time poorly will most likely neglect their academic work, which would lead to poor comprehension and ultimately failure as supported by the work of Nasrullah \& Khan (2015).

Moreover, it is expected that increase in family stress would lead to a reduction in academic performance. Respondents in this study who indicated family stress being responsible for their failure also indicated poor time management. Students who have problems at home most times lose focus and cannot concentrate on their academics as asserted by Siqueira \& Gurge-Giannetti (2011) and Rahamneh (2012). They search for other things that can relieve the burden from the stress and therefore engage in activities which reflect poor time management and increased absenteeism (Hidayat et al., 2012). Since the degree of relationship between inability to understand pharmacy courses and inadequate learning facilities is positively significant, it implies that one of the variables needed for students to fully understand pharmacy courses is the provision of efficient learning facilities. This is in line with the work of Ali et al. (2009) which showed that study-discipline from the student and the correct usage of the learning facilities put in place by the institution positively affected the student's performance.

Stiff competition, insufficient laboratory apparatus and congested lecture theatres are some of the possible side effects of having too large a class size from this study. The respondents agreed that these contributed to their withdrawal from pharmacy school and this further corroborates the study by Monks and Schmidt (2010) that class size has a negative impact on student outcomes. Congestion in the lecture theatres is not conducive to learning and demotivates undergraduates. Too large a class size also puts a strain on the limited institutional resources such as laboratory apparatus as implied in the study of Amua-Sekyi (2010). This also makes learning difficult and has been found to affect class participation, confidence and class preparedness (Bai \& Chang, 2016).

There was general improvement in the cumulative grade indices (GI) of the respondents in their new courses because most of them could manage their coursework load and could easily understand the assigned study material. Most of them also found their new courses of study interesting which would improve academic competence (Lust \& Moore, 2006). This result is indicative of the fact that students' perception of the course load and study material play a significant role in their academic performance. The results of this study also showed that most of the faculties the respondents transferred to had a lighter workload and study material compared to the Faculty of Pharmacy (Obafemi Awolowo University, 2019). This enabled some of the respondents who were withdrawn due to their inability to cope with the academic stress of the faculty of pharmacy to perform much better, in line with the position of Sallehuddin et al. (2019), who showed that improved academic performance was related to lesser workload. However, there was no significant difference in their cumulative Gl when in pharmacy and their cumulative GPA in their new programmes, this could be because the peculiarity of the pharmacy system which can ask a student with a fairly good Gl to withdraw based on not meeting the criteria for promotion to the next level (Obafemi Awolowo University, 2019).

Engaging in other activities has had a positive impact on the academic performance of the respondents in their new department(s). This assertion was confirmed when the respondents disagreed with the notion that engaging in other activities had had a negative impact on their academic performance. 
The importance of the ability to manage workload cannot be over emphasised. Studying continuously for long hours may create fatigue and overall exertion among students, which may lead to lower performance in examinations (Sariem et al., 2014). The inability to combine and organise study and leisure time due to the encumbrance of a crippling workload often reduces academic performance. This therefore explains the positive correlation seen between ease of having an organised study and leisure time and a net positive impact of engaging in other activities on academic performance.

The study was limited by the difficulty of reaching some of the respondents who had graduated and the challenge of getting some of the respondents to fill the questionnaire due to the sensitive nature of the topic. However these were overcome through phone calls to the respondents who had graduated and involving a familiar face in reaching out to the respondents affected. Also, getting the list of the withdrawn students in order to obtain an accurate population size took a long while. The five academic sessions studied revealed higher male drop out rates which is in line with the findings of Hassell et al. (2007). This issue merits further research. There would also be need for further studies that would cover institutions with diverse curricula content and conditions for progression in the course.

\section{Conclusion}

The study identified several causes of academic failure among students withdrawn from the faculty of pharmacy: excessive workload, poor time management, inadequate learning facilities, engagement in extracurricular activities, financial stress, stress from families and poor comprehension of lecture materials. Also, a large class population was perceived as contributing to undergraduate withdrawal. Furthermore, the withdrawn students performed better in their new courses mainly due to having a better understanding of the lecture materials, reduced workload, ease of combining study and leisure time, greater interest in subjects taught and reduced volume of course materials.

\section{References}

Abdulkarem, A.R. (2014). Extending the role of pharmacists in patient care: Are pharmacists in developing nations ready to change? Pharmacology and Pharmacy, 5, 865-875. https://doi.org L10.4236/pp.2014.59097

Akomolafe, C.O., \& Adesua, V.O. (2016). The Impact of Physical Facilities on Students' Level of Motivation and Academic Performance in Senior Secondary Schools in South West Nigeria. Journal of Education and Practice, 7, 4
Akubue, P.I., \& Adenika, F.B. (2009). Pharmacy Education in Nigeria: Proceedings of the Pharmacy Curriculum Conference, organized by the Pharmacists Council of Nigeria, 28-30 August, 2001. 2nd ed.

Ali, N., Jusof, K., Ali, S., Mokhtar, N., \& Salamat, A.S.A. (2009). The Factors Influencing Students' Performance at Universiti Teknologi Mara Kedah, Malaysia. Management Science and Engineering, 3(4), 81-90

AACP [American Association of Colleges of Pharmacy]. (2014). Annual Report: Profile of Pharmacy Students: Fall 2014 Available at: https://www.aacp.org/node pdf

AACP [American Association of Colleges of Pharmacy]. (2019). Annual Report: Profile of Pharmacy Students: Fall 2019 Available at: https://www.aacp.org/node pdf

Amua-Sekyi, E.T. (2010). Teaching in Universities in Ghana: The tensions and dilemmas. Ghana Journal of Education Teaching, 9, 141-149

Bai, Y., \& Chang, T. (2014). Effects of class size and attendance policy on university classroom interaction in Taiwan. Innovations in Education and Teaching International, 53 (3), 1-14. https://doi. org/10.1080/14703297.2014.997776

Blake, R.L., \& Vandiver, T.A. (1988). The association of health with stressful life changes, social supports, and coping. Family Practice Research Journal, 7 (4), 205-218

Blaney, C., \& Mulkeen, S. (2008). Student Retention in a Modular World - A Study of Student Retenton UCD Entrants 1999-2007. Dublin: University College Dublin

Buckley, P., \& Lee, P. (2018). The impact of extra-curricular activity on the student experience. Active Learning in Higher Education, 1-12. https://doi.org/10.1177/1469787418808988

Cameron, J., Roxburgh, M., Taylor, J., and Lauder, W. (2010). Why students leave in the UK: an integrative review of the international research literature. Journal of Clinical Nursing, 20(7/8), 1086-1096. https://doi.org/10.1111/i.1365-2702.2010.03328.x

Dennis, J.M., Phinney, J.S., \& Chuateco, L.I. (2005). The role of motivation, parental support, and peer support in the academic success of ethnic minority first-generation college students. Journal of College Student Development, 46, 223-236. https://doi. org/10.1353/csd.2005.0023

Department for Children, Education, Lifelong Learning and Skill (2009). Student Withdrawal from Higher Education, Research Document No: 042/2009. Wales: Dep. For Children, Education, Lifelong Learning and Skill

Dobson, I.R., \& Sharma, R. (1999). Student Performance and the Cost of Failure. Tertiary Education and Management, 5, 139-155. https://doi.org/10.1023/A:1018724614633

Dyson, R., \& Renk, K. (2006). Freshmen adaptation to university life: Depressive symptoms, stress, and coping. Journal of Clinical Psychology, 62 (10), 1231-1244. https://doi.org/10.1002/jclp.20295 Entwistle, N., \& Ramsden, R. (1983). Understanding Student Learning. Croom Helm London

Erhun, W.O., \& Rahman, A.W. (1989). Comparative Appraisal of the Pharmacy Curriculum at a Nigerian University. Journal of Social and Administrative Pharmacy, 6 (2), 92-98 
Fakeye, T.O., Adisa, R., \& Erhun, W.O (2017). Developing a model for teaching and learning clinical pharmacy components of the pharmacy curriculum in Nigeria. Pharmacy Education, 17(1), 60-66

Fisher, R., \& Engemann J. (2009). Factors Affecting Attrition at a Canadian College. Canadian Council on Learning, 6-8

Gavin, R.B. (2012). An Exploration of Potential Factors Affecting Student Withdrawal from an Undergraduate Music Education Program. Journal of Research in Music Education, 60(3), 310-323. https://doi.org/10.1177/0022429412454662

Gettinger M., \& Seibert J.K. (2002). Contributions of Study Skills to Academic Competence. School Psychology Review, 31, 350-65. https://doi.org/10.1080/02796015.2002.12086160

Graeff-Martins, A.S., Oswald, S.O., Comassetto, J.O., Kieling, C., Goncalves, R., \& Rohde, L.A. (2006). A Package of Interventions to Reduce School Dropout in Public Schools in a Developing Country: A Feasibility Study. European Child and Adolescent Psychiatry, 15(8), 442-449. https://doi.org/10.1007/s00787-006-0555-2

Grayson, J., \& Grayson, K. (2003). Research on retention and attrition. Montreal, QC: Canada Millennium Scholarship Foundation, 6-8

Greenberg, S.F., \& Valletutti, P.J. (1980). Stress \& helping professions. Baltimore: Paul H. Brookes

Hanna, L., Davidson, S., \& Hall, M. (2017). A questionnaire study investigating undergraduate pharmacy students' opinions on assessment methods and an integrated five-year pharmacy degree. Pharmacy Education, 17(1), 115 - 124

Hansen, J.B. (2000). Likely Factors Affecting the Academic Performance of Students. Journal of Educational Research, 89(3), 155-162

Hassali, A.M. (2011). Challenges and future directions for public health pharmacy education in developing countries. American Journal of Pharmacy Education, 75(10), Art.195. https://doi.org/ 10.5688/ajpe7510195

Hassell, K., Seston, E., Eden, M., \& Willis, S. (2007). The UK pharmacy degree: Attrition rates and demographics of non-completers. Pharmacy Education, 7(3), 249-256. https://doi. org/10.1080/15602210701589744

Hidayat, L., Vansal, S., Kim, E., Sullivan, M., \& Salbu, R. (2012). Pharmacy Student Absenteeism and Academic Performance. American Journal of Pharmacy Education, 76(1), 8. https://doi.org/ 10.5688/ajpe7618

IBM Corp. (2011). IBM SPSS Statistics for Windows, Version 20.0. Armonk, NY: IBM Corp.

Ikhile, I.J., \& Chijioke-Nwauche I.N. (2016). Pharmacy Education in Nigeria: The Progression. World Journal of Pharmaceutical Research, 5(7), 258-272

Johnson, G.M., \& Buck, G.H. (1995). Students' Personal and Academic Attributions of University Withdrawal. The Canadian Journal of Higher Education, 25(2), 55

Kirmani, N.S., \& Siddiquah, A. (2008). Identification and Analysis of Factors Affecting Students Achievement in Higher Education. 2nd International Conference on assessing quality in higher education, Lahore-Pakistan, 424-437
Kleijn, W.C., Vander, P.H.M., \& Topman, R.M. (1994). Cognition, Study Habits, Test Anxiety and Academic Performance. Psychology Reports, 75(3), 1219-26. https://doi.org/10.2466/pr0. $\underline{1994.75 .3 .1219}$

Lust, E., \& Moore, F. (2006). Emotional intelligence instruction in a pharmacy communications course. American Journal of Pharmacy Education,70, 6. https://doi.org/10.5688/aj700106

Mannan, M.A. (2007). Student Attrition and Academic and Social Integration: Application of Tinto's Model at the University of Papua New Guinea. Higher Education, 147-165. https://doi.org/ 10.1007/s10734-005-2496-y

Mehta, S.S., Newbold, J.J., \& O'Rourke, M.A. (2011). Why do first-generation students fail? College Student Journal, 45(1), 20-35

Moeketsi, L., \& Maile, S. (2008). High University Drop-out rates: A Threat to South Africa's Future, HSRC Policy Brief. Human Sciences Research Council. Available at: https://www.worldcat/title/ high-university-drop-out-rates-a-threat-to-south-africas-future/ocl c/228420037

Mokula, L.L.D., \& Lovemore, N. (2014). Forms, Factors and Consequences of Cheating In University Examinations: Insight from Open and Distance Learning Students. Turkish Online Journal of Distance Education, 15(4), 17. https://doi.org/10.17718/ tojde. 89240

Monks, J., \& Schmidt, R. (2010). The Impact of Class Size and Number of Students on Outcomes in Higher Education. Cornell University, School of Industrial and Labor Relations. Available at: http://digitalcommons.ilr.cornell.edu/workingpapers/114/

Nasrullah, S., \& Khan, M.S. (2015). The Impact of Time Management on the Students' Academic Achievements. Journal of Literature, Languages and Linguistics, 11, 66-72

Nicpon, M., Huser, L., Blanks, E., Sollenberger, S., Befort, C., \& Kurpius, S. (2006). The relationship of loneliness and social support with college freshmen's academic performance and persistence. Journal of College Student Retention: Research, Theory, and Practice, 8, 345-358. https://doi.org/10.2190/ A465-356M-7652-783R

Obafemi Awolowo University (2019). Faculty of Pharmacy Handbook 2019-2021. Obafemi Awolowo University, Nigeria. Available at: https://oauife.edu.ng/images/pharmacy/pharmacy handbook2019.pdf

Oduwaiye R.O., Yahaya, L.A., Amadi, E.C., \& Tiamiyu, K.A. (2017). Stress Level and Academic Performance of University Students in Kwara State, Nigeria. Makerere Journal of Higher Education, 9(1), 103-112. https://doi.org/10.4314/majohe.v9i1.9

Okogbaa, J., Allen, R.E., \& Sarpong, D.F. (2020). Time Spent at Work and Its Impact on the Academic Performance of Pharmacy Students. International Journal of Environmental Research and Public Health, 17(2), 1-13. https://doi.org/10.3390/ijerph17020496

Ortiz-Lozano, J.M., Rua-Vieites, A., Bilbao-Calabuig, P., \& Casadesús-Fa, M. (2018). University student retention: Best time and data to identify undergraduate students at risk of dropout. Innovations in Education and Teaching International, 74-85. https://doi.org/10.1080/14703297.2018.1502090 
Otto, M.D. (1988). An Analysis of the Predictors of Early Academic Dismissal. Research in Higher Education, 28, 34-48. https://doi. org/10.1007/BF00976858

Pariat, L., Rynjah, A., \& Kharjana, J.M.G. (2014). Stress Levels of College Students: Interrelationship between Stressors and Coping Strategies. Journal of Humanities and Social Science, 19(8), 40-46. https://doi.org/10.9790/0837-19834046

Pinto, M.B., Parente, D.H., \& Palmer, T.S. (2001). College student performance and credit card usage. Journal of College Student Development, 42(1), 49-58

Powell, D.H. (2004). Behavioural treatment of debilitating test anxiety among medical students. Journal of Clinical Psychology, 60, 853-65. https://doi.org/10.1002/jclp.20043

Rahamneh, K.F.A.. (2012). Reasons for the Low Academic Achievements among the Students of the Main Stages in Selected Schools in the Province of Al-Balqa. Ozean Journal of Social Sciences, 5(1), 31-40

Rumberger, R.W., \& Lim, S.A. (2008). Why Students Drop Out of School: A Review of 25 Years of Research. California Dropout Research Project Report \#15

Rushforth, H.E. (2007). Objective structured clinical examination (OSCE): review of literature and implications for nursing education. Nurse Education Today, 27(5), 481 490. https://doi.org/10.1016/ j.nedt.2006.08.009

Sallehuddin, M., Huzaidy, A.H., \& Rosli, N.M. (2019). The Relationship between Stress, Workload and Time Management towards Academic Performance among Working Postgraduate in Universiti Utara Malaysia (UUM). American International Journal of Business Management, 2(11), 45-55

Scherer, S., Talley, C.P., \& Fife, J.E. (2017). How Personal Factors Influence Academic Behavior and GPA in African American STEM students. SAGE Open, 7(2). https://doi.org/10.1177/2158244 017704686

Siqueira, C.M., \& Gurge-Giannetti, J. (2011). Poor School Performance: An Updated Review. Revista da Associação Médica Brasileira, 5(1), 78-86. https://doi.org/10.1016/S2255-4823(11) $\underline{70021-2}$

Sujit, S.S., Monali, B., \& Sail, K. (2006). Factors that Affect Academic Performance among Pharmacy Students. Americam Journal of Pharmacy Education, 70(5), 104. https://doi.org/10. 5688/aj7005104

Talib, N., \& Sansgiry, S.S. (2012). Determinants of Academic Performance of University Students. Pakistan Journal of Psychological Research, 27(2), 265-278

Wills, T.A. (1991). Similarity and self-esteem in downward comparison. In Social Comparison: Contemporary Theory and Research, (Eds. J. Sulus \& T.A. Wills), Lawrence Erlbaum Associates, Hillsdale, NJ,51-78

Yamane, T. (1967). Statistics: An Introductory Analysis, 2nd Edition, New York: Harper and Row

Yorke, M., \& Longden, B. (2008). The first-year experience of higher education in the UK. York, UK: The Higher Education Academy 